\title{
比較神経解剖学と比較認知科学の統合
}

\author{
慶応義塾大学文学部 渡辺 茂
}

\section{Integration of comparative neuroanatomy and comparative cognition}

\author{
SHIGERU WATANABE \\ Faculty of letters, Keio University
}

\begin{abstract}
Neuroanatomy is a science of form, whereas cognitive science is a science of function. Comparative neuroanatomy and comparative cognition, however, share a common interest, that is, the evolution of form and function. Pigeons and humans show apparently similar higher visual cognition, but their brain mechanisms are different. Functional constraints caused by differences in the brain structures are still unknown. Interpretation of function by form is the traditional way of explanation in biological sciences, and hence the integration of comparative neuroanatomy and comparative cognition should provide such an approach.
\end{abstract}

Key words : evolution, brain, avian visual system, comparative psychology

\section{0 ) はじめに}

ごく少数派の人たちは言う。「機能抜きの神経解 剖研究はナンセンスだ, 神経解剖抜きの機能研究は 总惰だ。」

本稿は2007年の日本動物心理学会の会長講演を元 にしたものである。心理学の中で動物心理学はマイ ノリティである。筆者は鳥類を被験体とすることが 多いが, 鳥の研究では神経科学や神経解剖はやはり マイノリティである。以下，どこに行ってもマイノ リティである筆者がなんとか一分の存在を主張する ごまめの歯ぎしりである。

\section{1 ) 比較認知科学}

行動を比較する際に比較解剖学を参考にしようと いうのがコンラット・ローレンツが比較行動学 （Ethologie）を構想した時のアイデアであった (Lorenz，1978)。化石資料がほとんど求め得ない 行動においては, その進化を再構成するには現存動 物の比較から行ら他ない。そこから現存動物の行動 にいかに相同関係を求めるかといら研究が始まった

Published online in J-STAGE: December 11, 2008 doi: 10.2502/janip.58.2.5
のである。比較行動学が当初から異なる種での比較 を行っていたのに対し，心理学における動物実験は 少数の種のモデル動物での行動の一般理論の構築を 主眼においていた。行動主義心理学以前にも W. Wundt は擬人主義による動物心理学を提唱してい るし (Wundt, 1894), 進化論はその心理版という べき J. G. Romanes の動物心理学を生み出してい る (Romanes, 1883)。C. L. Morgan の動物心理 学もまたヒトの内観からの演繹による心理学である (Morgan, 1894)。しかし, 彼らが考えた「心の進化」 は畢竟ヒトの心理を頂点とする単線的な進化観であ る。Morganの弟子であった M. F. Washuburn の ように動物の意識そのものを研究対象とした心理学 者もいるし(Washburn, 1917), 米国においては, T. C. Schneirla のように比較そのものを標榜した心 理学者もいたが (Maier \& Schneirla, 1935), や はり一時期の心理学における動物研究は一般理論, とくに学習の一般理論の構築に主眼が扔かれていた というべきだろう。

いわゆる認知革命について，あらためて述べるこ とはしないが，時代精神として「認知」という言葉 の「自由化」(liberalization) が起きたことは否め ない。神経科学ではJ. O’keef とL. Nadelの「認知 
地図としての海馬」が登場したし(O’keef \& Nadel, 1978), 動物行動学においてはD. R. Griffinの認知 動物行動学が登場した (Griffin, 1976)。現在では認 知生態学 (cognitive ecology), 認知鳥類学 (cognitive ornithology) といった用語も登場するようになった。 いまや，自由化というよりインフレといらべきかも 知れない。

認知科学自体はむしろ, 実行機関が機械であるか, ヒトであるか, あるいは動物であるかを問わない, 認知の一般理論を目指寸のが正統だと思われる。も ちろん, 認知科学, とくに認知心理学の出自は単系で はないので，らんざりするほどメンタリスティック なものから計算論一本槍のものまでさまざまな展開 がある。いずれにしても比較認知科学が認知の一般 理論の頑健性を実証するためにさまざまな動物での テストを行う, という立場でもないかぎり認知科学 の中では異端というべきだろう。比較行動分析とい う言葉も登場したが，これは短命に終わったようで ある。行動分析の創始者である B. F. Skinner 自身 は系統発生的随伴性 (phylogenetic contingency) に十分関心があったのだから，これは少々気の毒に も思える。不肖の弟子が多かったというべきか。

比較認知科学の目的には, ヒトの心理の理解のた めにその進化的起源を明らかにする，というものと， 様々な動物の行動の多様性そのものの理解から,

「心」と言語的に記述される神経系の一連の機能が どのように発生し, 進化をとげたかを理解しようと するものがある。前者はローレンツ以来の正統であ る。後者は極端にいえばある種の心の相対主義の立

\section{Edinger-MaClean's model}

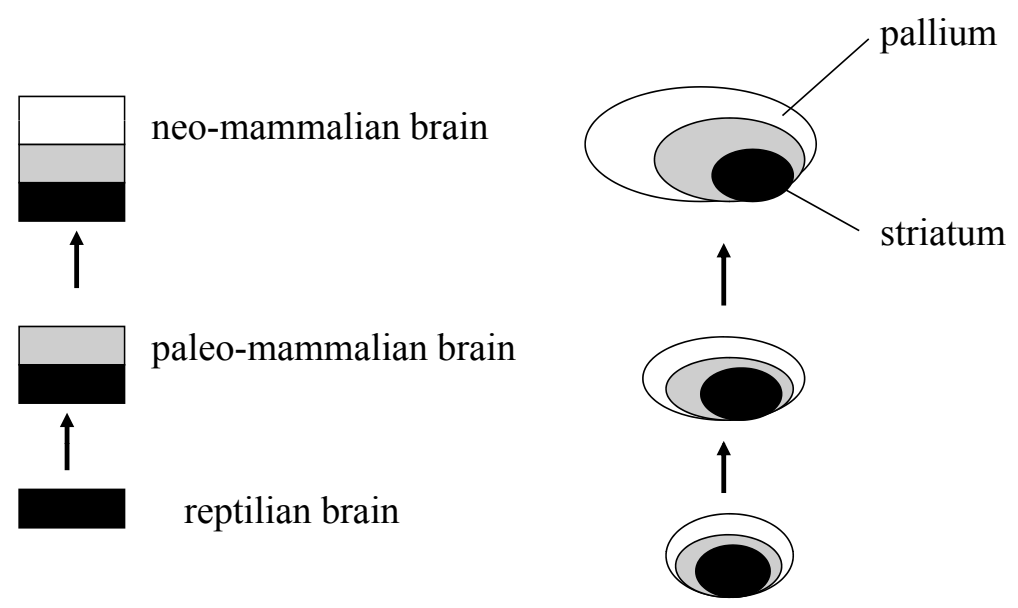

場であるが，厳密には文化相対主義がそうであるよ うに多くの問題点を内包している（渡辺，1998）。

\section{2 ）比較解剖学の目的と歴史}

比較認知科学がついこの間誕生したのに対し, 比 較解剖学は長い歴史を持っている。さまざをな科学 がそうであるようにアリストテレスに遡ることがで きる。しかし, 近代の比較神経解剖学は19世紀末か ら20世紀初頭の誕生とみることができる。つまり，C. Golgi, R. y. Cajal, J. B. Johnstone, L. Edinger, K. Brodmann といった巨人たちが登場した時代で ある。Nieuwenhuys（1998）は「比較神経解剖学 の目的は中枢神経系とその部分の形態, 構造の解明 である」としており，機能は含まれていない。つま り，「何であるか」という問いであり，「何をするか」 といら問いではない。しかし，さらに深読みをする と形に違いがあれば機能に違いがあるのは当然だと いう前提があるのかもしれない。Brodmannの脳地 図は彼の顕微観察の主観的判断によるものだが，い まだに機能研究で参照される。

生物科学に打ける比較研究の目的は進化の解明で あるが，現在まで続くいくつかの論争がある。あら ゆる動物はひとつの祖先 (proto-animal) から出発 したとするのか, 複数の祖先から出発したとするの かは論争者の名前に因んでCuvier-Geoffroy 論争と いわれるものである。Streider（2007）によれば, これは未だに解決されていない問題だといら。例え ば, 脊椎動物の神経系は胚の背側部から発生するが, 無脊椎動物では腹側部から発生する。このことは,

Johnston's model

Figure 1. Edinger-MacLean's model (left) and Johnstone's model (right). Many neuroanatomists support the latter model recently. 
脊椎動物と無脊椎動物では神経系の起源が違うこと を示唆するように思える。しかし，脳や目の形態形 成に関わる転写因子 Pax6はショウジョウバエでも プラナリアでもマウスでもヒトで共通である。この ことは共通の形態形成の機構を示唆する。

もう一つの重要な論点は脳における「新しい」部 位の出現である。もともとは Edinger（1908）のア リストテレス的な自然の階段という考え方に立脚す る。脊椎動物の進化の過程でたえず新しい部分が古 い部分にくわわるといら形で脳が進化してきたとす る。脊椎動物の大脳でもっとも古い部分は線条体で あり, 原始的な脊椎動物である魚類は旧線条体 (paleostriatum) しか持っていない。これはヒト の淡蒼球（globus pallidus）にあたる。両生類は これに加えて, ヒトの扁桃体に相当する原線条体 (archistriatum) を持つ。爬虫類になるとさらに すすんだ新線条体 (neostriatum) を持ち，これは ヒトの尾状核 (caudate nucleus), 被款 (putamen) に相当する。大脳背側部は外套（pallium）になる が魚類では $2-3$ 層の旧外套しかもたないのに対し， 爬虫類は原外套をもち, ヒトは 6 層の新皮質をもつ に至る。この考え方は後に MacLean（1970）が, 爬虫類脳, 原哺乳類脳, 新哺乳類という区分をし, われわれの脳のなかには爬虫類の脳があるといら素 人受けのする表現をしたため，今日でもこの考えを 鵜吞みにしている研究者がいる。

しかし,別の考え方は脊椎動物の脳は基本的に同じ 構造をもっているとするものである。J. B. Johnstone Club (比較神経解剖学の学会) にその名前をとどめ ている Johnstone（1923）がその考え方の典型であ る。彼は脳の進化の中で全く新しい構造が突如出現 したことはないと主張している。たとえば, 哺乳類 の大脳の特徵は新皮質といわれる層構造で 6 層に細 胞が分かれた美しい構造がみえる。P. D. MacLean によれば，これは哺乳類が獲得した新しい脳である。 両生類の大脳には層構造のある新皮質がないがいく つかの部分に分かれた外套がある。このうち内側外 套は哺乳類海馬に相当すると考えられるが, 背側外 套は新皮質に, 外側外套が嗅皮質に相当すると考え られる。その理由は視床からの投射にある。両生類 背側外套は哺乳類新皮質と同様に背側視床から投射 をうける。爬虫類になると背側外套はD 1, D 2 に 分けられ, 背側視床から視覚系の入力をらけるのは D 2 の方である。このように哺乳類の新皮質は突如 現れたものではなく, 両生類までその起源をたどる ことができる。

鳥の脳の名称は Edniger-MacLean の発想にした がって命名されていた。つまり大脳のほとんどの部 位は線条体とされていたのである。これが不適切だ
ということは1960年代から言われていたが，実際に 改名がおこなわれたのはごく最近になる。1997年か らデューク大学のE. D. Jarvis, テネシー大学のA. Reiner, オークランド大学の M. Wild, 南フロリダ 大学の清水透らが中心となって構想が練られていた。 米国の国立科学基金と国立衛生研究機関の援助を得 て,デューク大学でおよそ30人の研究者を集めた会議 が開かれ, 名称変更に至った (Reiner et al., 2004)。 合意に達した新しい考え方では大脳における, 外套, 線条体, 淡蒼球はすべての脊椎動物に共通する構造 だと考える。すなわち，魚類においてもこれらの構 造は最初から存在するのであり, 爬虫類や哺乳類に 進化することによって魚の脳につぎつぎと新しい構 造が加わっていくものではない。外套は動物によっ て構造の違いが見られ, 高外套は鳥類にしか見られ ず，中外套，巣外套，古外套からなるDVR (dorsal ventricular ridge) は鳥類と爬虫類に特徵的な構造 である。他方，新皮質は哺乳類のみに見られる。鳥 の大脳の大きな部分は哺乳類の皮質と同じカテゴ リーになったのである。なお，海馬，嗅皮質などで は名称変更はなかった。

\section{3) 脳の全体的進化}

脳の進化の評価には, 脳の絶対的な大きさも用い られるが, 脳重/体重のアロメトリーがよく用いら れる。アロメトリーは T. H. Huxley らによって導 入された考え方であり，例えば体重と脳重の関係之 いった測度間の関係を問題にし, 脳研究においても 多く用いられている (Healy \& Rowe, 2007)。特 筆すべきは Jerison（1973）が非常に早い時代に脳 の増大と知能を関連づけていたことで，その後の多 くの脑進化と心の進化を結びつける研究の喵矢と なった。

脳は神経細胞（とグリア細胞）からできているが， 細胞自体はそうそう小さくすることはできない。他 方, 生存に必要な基本的な機能はヒトでもネズミで も同じように必要である。歩くためには足を動かさ なくてはならないし, 感覚情報の処理もしなくては ならない。小さな動物は相対的に脳が大きくなるが, これは, 神経細胞といら脳の素材による制約である。 体の大きさと脳の大きさに一定の関係はあるのだか ら，その一般式を作り，その係数として脳の大きさ をしめすことはできる。これが脳化係数である。両 者の関係は次のように表せる。

\section{脳化係数 $\mathrm{H}=\mathrm{K} \times \mathrm{C}^{\mathrm{a}}$}

ここで $\mathrm{H}$ は脳重， $\mathrm{C}$ は体重， $\mathrm{a}$ は常数，そして $\mathrm{K}$ が係数になる。本来は 2 つの実測值 $\mathrm{H}$ と, 2 つの 未知数 $\mathrm{a}$ と $\mathrm{k}$ があるわけだから，この式は解けない 
が、については経験的に求める。Dubois (1987) は 似たような動物（たとえばネコとトラ）が同じ K を 持つことを仮定して a を計算している。したがって, いくつかの值が提唱されているが，よく知られてい るのはvon Bonin (1937) の2/3というものであろう。 これはほぼ表面積に対応する。もう一つよく使われ る0.75は基礎代謝率に対応する。

もうひとつの指標は期待值との差を使うものであ る。さまざまな動物の体重と脳重の両対数関係を図 に記していくと多角形ができる。その主軸をもとめ る。主軸の上にある動物は体の割に脳がおおきく, 下の動物は脳が小さいといらことになる。動物の体 重がわかれば，そこから期待される脳重がわかる。 期待值 $(\mathrm{Ee})$ と実測值 (Et) の比率をとれば, 脳 の大きさの指標, 脳化指数を計算できる。

\section{脳化指数 $=\mathrm{Et} / \mathrm{Ee}$}

しかし, 直線の傾きはデータに依存するから, 哺 乳類だけで計算した場合と脊椎動物全体で計算した 場合では傾きが異なってくる。

このようにして体重と脳重の関係を図にしてみる と, 春椎動物のなかで脳を大きくしたグループとそ うでないグループがあることがわかる。哺乳類と鳥 類は脳を発達させたグループであり, 魚類や爬虫類 は脳を発達させなかったグループである。脳は多く の酸素, 多くの糖を必要とするコストのかかる器官 であるから小さな脳にするのもひとつの適応戦略な のである。哺乳類ではヒト, 象, クジラなどが特に 脳を大きくしている。鳥類ではオウムやカラスが脳
を大きくしている。恐竜のなかにも脳が大きいもの がいるし，魚類ではクマノミなどが大型脳である。 大型脳グループと小型脳グループの違いはあるが, それぞれのグループのなかでまた脳を大きくした種 とそうでない種がある。このことは脳の大型化が進 化のなかで相互に独立に何回も生じていることを示 唆する。小型脳への進化も見られる。硬骨魚類では ウナギが, 両生類ではサンショウウオが脳を小型化 している。

あまり見かけなくなったが Progressive Index (PI) というものもある。

Progressive Index (PI)

$$
=\text { brain/brain of reference species }
$$

この式は，原型となる動物から脳がどのくらい大 きくなったかを示すものである。もちろん，本来の 原型動物は存在しないので, 哺乳類の場合は食虫類 などを参照動物とする。なお，ヒトのPIは3000であ る (Baron, 2007)。

脳の大きさの測定は簡単そうに思えるがいくつか の技術的問題がある。まず標本のサンプリングの問 題がある。ある動物種のたくさんの標本があるわけ ではないから，その標本が本当にその種を代表して いるかという問題がある。野生動物の場合, 年齢, 性, 健康状態などを一致させることは難しい。また, 測 定する脳は通常固定されている。したがって, 固定 液による収縮も問題になる。収縮を補正する式も作 られているが, 収縮の程度は脳の組織に依存するか ら, 一様に収縮するわけではない。化石資料で頭蓋

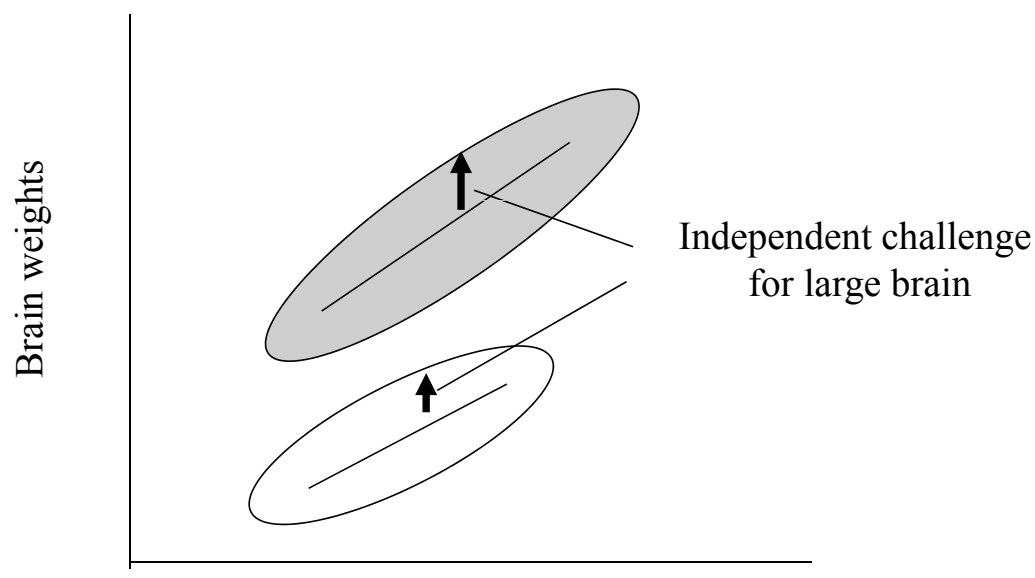

Body weights

Figure 2. Relationship between body weights and brain weights. There are large brain groups and small brain groups in vertebrates. Some species in each group challenged to have bigger brains. 
から脳を推定する際には別の問題もある。たとえば, 爬虫類では頭蓋と脳の間に隙間があり, 正確な脳の 推定を妨げている。最後に統計学上の問題もある。 哺乳類の場合, 多くの辡歯類のデータがあり, した がって回帰直線を用いる場合には, 䛚歯類にバイア スがかかることになる。最小多角形の主軸ではこの ようなバイアスを避けることができる。直線の推定 にはさまざまな方法があるが，幸いなことにそれほ どの差はでない。なお, 脳全体の大きさの機能的意味 についてはそれを疑う意見もある (Healy \& Rowe, 2007)。

\section{4 ）脳の部分的進化}

動物の脳の外見が違うのは発達している部位が違 らからである。ネズミの脳はヒトの脳の縮小コピー ではない。ネズミの脳で発達している嗅球はヒト脳 では大脳皮質に隠れて底からみなくてはわからない。 逆にヒト大脳の回はネズミにはない。哺乳類と鳥類 では脳のなかでも大脳が大きい。一方, 鳥類と魚類 の類似点は中脳が大きいことである。中脳はもとも と視覚脳であり, 魚類, 鳥類が視覚動物であること を示す。魚類, 鳥類とも水中か空中かという違いは あっても運動が 3 次元的であり，このことと中脳の 発達とは関係がある。このような相対的な形態の変 化があるのは脳がモザイク型進化といわれるものを するからで, 脳のある部分の増大は他の部分に影響 を与えず独立に大きくなる場合がある（Barton \& Harvey，2000)。上丘はラットでは小さくジリスで は大きいが他の大脳や小脳の大きさは両者でかわら ない。モザイク進化の評価のひとつは前述したPIの ようなもので, 参照としてある部位, 通常は脳幹や 線条体をとり, 他の部位の差別的発達を示すもので ある。もちろん, ある部分の増大はそれに付随して

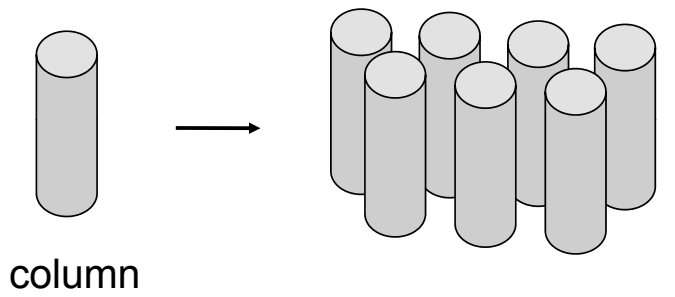

\section{Radial unit hypothesis}

Figure 3. Evolution of neocortex. The neocortex consists of columns, thus enlargement of neocortex means increment in number of the column. Enlargement of cortex is, therefore, radiation in the horizontal plane.
他の部分の増大をおこす場合があり，これは受動的 進化といわれる。

脳のある部分の発達は機能の発達と関係する。あ る機能を担っている神経組織の量はその機能の量に 対応している。ある部位が大きくなれば,他の部位へ の投射一侵入し, かつ新しい投射も獲得する。つまり, ある部位が大きくなることは細胞が多なるばかりで なく，ネットワークが大きくなることを意味する。 哺乳類の大脳皮質を比較すると表面積は小さいもの から大きいものまで 1 万倍くらいの違いがあるのに 対し, その厚みはせいぜい10倍程度の違いである。 つまり，大脳皮質は厚さではなく水平方向に広がっ たのである。新皮質では縦方向の円柱 (column) が ひとつの機能単位となっており，この円柱をなら心゙ たものが皮質なのである。水平方向への発展は結局 この円柱の数的増大である。

大脳の進化でもうひとつ重要なものは白質, つま り線維連絡の増大である。白質の進化は非線形的で ある。霊長類で比較するとマーモセットでは白質が 脳にしめる割合は $10 \%$ 以下だが，ヒトでは $34 \% に も ~$ なる。皮質面積の増大要請に対する回答のひとつは 回による表面積の拡大であるが，回むむやみに多く できない。皮質と皮質の間には連絡のための空間が 必要だからである。ホフマン（Hofman, 2001） は 情報処理器官としての脳の進化のシミュレーション をおこなっている。脳全体が $3000 \mathrm{~cm}^{3} の$ 霊長類を想定 すると白質の割合は $1 / 2$ にもな（実際のヒトでは $1 / 3$ )。大脳皮質（扊白質と白質）の増大は皮質下の 構造の大きさを圧迫する。脳全体が3500 $\mathrm{cm}^{3} の$ 時に大 脳皮質の構造が最大值になり，それ以上大脳皮質を 増大させると皮質以外の構造は小さくなり始め, 8750 $\mathrm{cm}^{3}$ では理論上 0 になってしまう。これらのこと からホフマンは, 特別な進化がないかぎり, 現在の ヒト脳の $2-3$ 倍の大きさで情報処理器官としては 限界に達するとしている。

\section{5 ) 成因的相同と系統分岐分析}

Simpson（1961）は相同を共通祖先に戻れる形質 であると定義した。位置の類似性, 線維連絡の類似 性, 中間種における類似性の連続性といった形態的 には部分相互の相対的位置が相同の定義とされる

(Nieuwenhuys，1998)。相同関係になくても形が 類似する場合がある。成因的相同 (homoplasy) と いわれるものである。系統分岐分析を神経解剖学に 導入したのは Northcutt（1984）である。もし，あ る種がある形質を獲得すると，それ以降に出現した 種はその形質を保持することになる。しかし，類似 した形質が進化の過程で独立に出現する場合もある。 たとえば，大脳の回，いわゆる甮の発達はヒトの大 
脳の特徴であるが, 同時にゾウやイルカ, トゲネズ ミにも見られる。したがって，相同ではなく成因的 相同なのである。系統分岐分析は特定の形質の進化 の研究には有効な方法であるが, 種の進化について は問題点がないわけではない。それは分析に使われ る形質への依存性である。違う形質のセットによっ て分析を行うと別の結果が出る可能性がある。相同 の定義である共通祖先の同定には化石研究が欠かせ ないが, 行動ほどではないが, 脳のような軟組織は 化石として残りにくい。

\section{6) 鳥類視覚認知と視覚脳}

実験心理学の初めの実験動物はネズミであったが, やがてハトが多く用いられるようになった。その理 由のひとつにヒトは視覚動物であるが, ネズミはそ うではなく，一方，八トは視覚動物であるというこ とがある。もちろん, ヒト視覚系と八ト視覚系には 多くの違いがある。まず，目のつき方が違う。ヒト の目は顔の前方についているが，ハトの目は側方に ついている。したがって，両眼視野はヒトで大きく ハトで小さい。ただし, これは哺乳類と鳥類の違い ではない。草食動物の多くは側方眼をもっているし, 鳥類でもフクロウなどは前方眼である。一般に遠く を監視する被捕食者は側方眼が多く, 最終的に近間 の接近戦をしなくてはならない捕食者は前方眼が多 い。さらに中心窩にも違いがある。側方眼である八 卜は前方視のための中心窩と側方視のための中心窩 を持っている。機能的には広い範囲を監視しながら 餌を豚めることになるが，この視覚世界をヒトが想 像することは難しい。ヒト眼底は血管に富んでいる が，ハト（鳥類）では櫛状器官がその役割を果たし ている。網膜レベルでも違いがある。ハトでは光が 視細胞で膜電位に変換される前に油粒といわれるカ ラーフィルターを通るがヒト網膜ではそのようなも のはない。視細胞の感受性にも違いがある。視細胞 は選択的な変換器であるが, 電磁波の一部しか膜電 位に変換しない。ヒトの場合は変換できる電磁波の 範囲はおよそ400-700ナノメータであるが，八トの 場合は紫外線にも感受性がある。現在多くの視覚実 験で真空管または液晶のディスプレイが用いられる が，当然のことであるがこれらの色表示はヒトの視 覚系用に開発されたものであり，ハトにとっては波 長情報の欠落を意味する。

しかし，これらの末梢的な違いにもかかわらずハ トはヒトに比肩し得る高次な視覚認知を示す。この ようなハトの高次視覚認知研究の噮矢となった研究 はR. Herrnstein によるものである (Herrnstein \& Loveland，1964）。いまさら紹介するまでもないが, 彼らはそれまでの実験のように厳密に刺激を定義す
るのではなく多数の刺激を用いて，いわばノイズに あたる要素を中性化する方法をとった。この方法に より，どのような写真でも人間が写っている写真か そうでないかを八トに弁別させることに成功したの である。その後，さまざまな視覚概念の実験が行わ れた。概念あるいはカテゴリーは特定の刺激クラス 内の般化と刺激クラス間の弁別と定義される。この ような高次視覚認知の脳内機構も調べられている。 コンピュータグライックスを用いて，様々な三角形 と 3 本の線分の弁別を訓練すると, 八卜はある種の 「三角形」の視覚概念を形成できる。ただし，これ はヒトが学校教育でならう「任意の 3 点を結ぶ 3 本 の線分」といら定義とは異なる。詳細にテストする とハトが形成した刺激統制と人間の言語的な三角形 の定義とは異なることがわかる(Watanabe，2006)。 これはハトが結局随伴性を介して複雑な刺激統制を 学習しているのに対し，ヒトは言語による規則統制 行動を学習しているからだが，十分に随伴性を構成 していけば，かなり言語による規則統制行動に近い 刺激統制が形成されると思われる。同じような人工 的な刺激として絵画を使った弁別実験もある

(Watanabe et al, 1995; Watanabe, 2001b)。 この場合も特定の作風による刺激統制が可能で，見 かけ上，ヒト類似の視覚認知を示す。

より自然な弁別としては，個体弁別や種弁別，ま た食物の弁別などがある。八トは未知の 2 個体の静 止画像の弁別ができるし，その弁別は同じ個体の新 奇な画像一も般化する。八トとそれ以外の種の弁別, 自種をふくまない鳥の弁別，実物や写真を用いた餌 とそれ以外の物体の弁別も可能である。さて，この ような複雑な視覚認知は脳内でどのように処理され ているだろらか。

鳥類でも哺乳類でも網膜からの出力は $2 つ の$ 経路 をたどる。直接間脳（外側膝状体または背側視床） から大脳 (V 1 または高外套) に行く経路と中脳 (上 丘または視蓋）に行ってから間脳（視床枕または円 形核)，そこから大脳 (V4，V５ または内外套)へと 行く経路である。霊長類では, 外側膝状体 $-\mathrm{V} 1$ の 経路が主たる視覚情報処理の系である。一方，1960 -1970年代の W. Hodos らの一連の研究によって ハトでは中脳一大脳系が主要な視覚情報処理を担っ ていることがわかってきた。

筆者は高次視覚認知の脳内部位を明らかにするた めに一連の脳損傷実験を行った。その結果, 一対の 3 本線と三角形の弁別は内外套損傷によって, 障害 を受けないが，「三角形」の概念弁別は障害されるこ と (Watanabe, 1991), 個体弁別は内外套損傷で障 害されるが種弁別は維持されること (Watanabe, $1992 ； 1996)$, 高外套はどちらの弁別も障害されな 
Primates

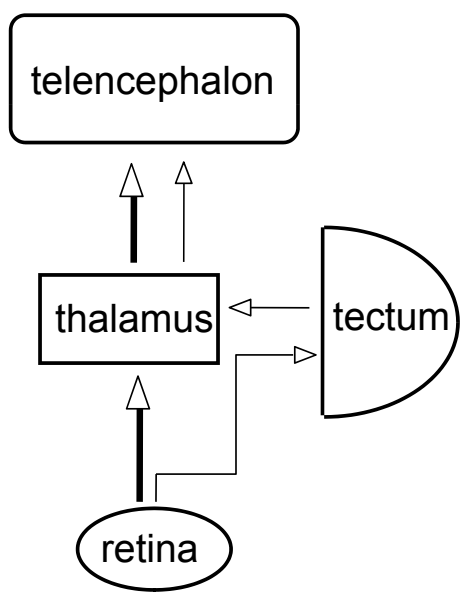

Birds

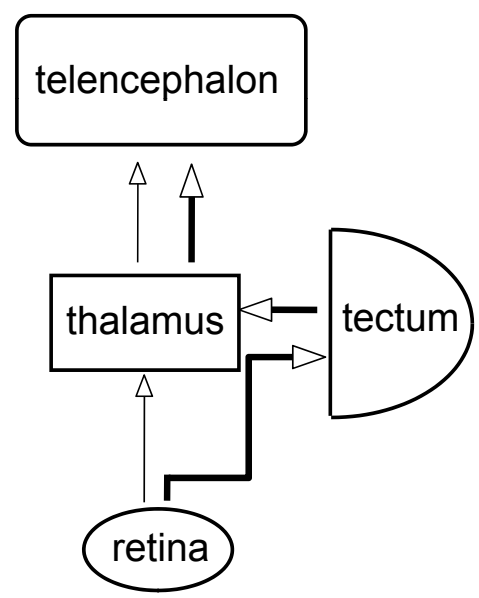

Figure 4. Primate visual brain (left) and avian visual brain (right). The thalamo-telencephalic pathway is the main rout of visual information processing in primates, whereas the tecto-thalamo-telencephalic pathway is the main rout in birds.

いこと，などを明らかにした。これらのことは，弁 別訓練を通じて獲得される「三角形」や個体弁別に は内外套が必要であるが, 単純な視覚弁別や, 被験 体が弁別それ自体としては実験以前から獲得してい たと推定される種弁別では必要ないといらことにな る。一方, 間脳一大脳形である高外套損傷はこれら の視覚認知に影響しない。つまり，鳥類の主要な視 覚情報処理の系は網膜から中脳にいく系といらこと になる。実際, 鳥類視蓋はV. Frostらの電気生理学 的研究によって霊長類V 5 のようなさまざまな運動 視を担っていることがあきらなになっているし，視 蓋損傷は回復不可能な視覚障害をおこす。

それでは霊長類の主要視覚情報処理系であった間 脳一大脳系は鳥類ではなにを処理していたのか。一 般的に高外套損傷は視覚認知障害をおこさない。筆 者は鳥類海馬機能に興味を持ち, 海馬機能を解明す るために連続位置学習といら課題を考案した。実験 的脳損傷の研究では同一個体で損傷前後の行動を比 較することが行われる。しかし，このパラダイムを 学習の獲得過程に適応することは難しい。つまり, 獲得はある種の破壊実験であり，2回繰り返すこと ができない。したがって, 通常は被験体間比較を行 らしかない。損傷実験で個体内比較を行らため, 行 動薬理学で開発された連続獲得課題に類似した課題

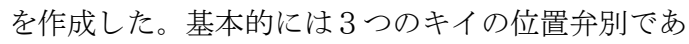
るが，任意のキイを $\mathrm{S}+$ とした同時弁別を訓練し，

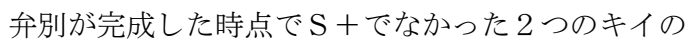

ひとつを $\mathrm{S}+$ とした訓練に切り替える。これを繰り 返すと被験体は位置弁別を繰り返し学習しなくては ならない。このようにして，位置学習の獲得のベー スラインを得ることができ，それを参照基線として 損傷前後の位置学習の獲得の変化を調べることがで きる。その結果, 海馬損傷によって位置獲得が著し く障害を受けることがわかった（Watanabe，1992）。 この課題の一般性を調べるためにラットを用いて 3 レバーの選択で同じ課題をおこなったところ，やは り海馬損傷で障害がみられた (神前, 未発表)。なお,

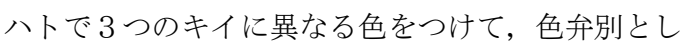
ても課題を学習できるようにすると海馬損傷効果は 消失する。

この時，統制実験として高外套および内外套損傷 もおこなった（Watanabe, 2003）。意外なことに視 覚認知課題であれほど顕著に障害を起こした内外套 はなんの障害もおこさなかった。もつとも3つのキ イの位置を見分けること自体は視覚的負荷の少ない 課題であるから，障害がでないことに不思議はない。 一方，視覚認知についてはサイレントであった高外 套損傷は海馬損傷に匹敵する障害を起こしたのであ る。筆者は当初, この課題がある種の逆転学習である ことから高外套によって起こされる障害は行動の可 塑性に関わる障害と考えていた（Watanabe，2006)。 しかし, その後, 海馬の感覚情報の入力を調心゙るう ちに, 鳥類海馬と哺乳類海馬の入力関係の相違に気 がついた。哺乳類海馬では感覚入力は嗅内皮質を介 
spatial discrimination

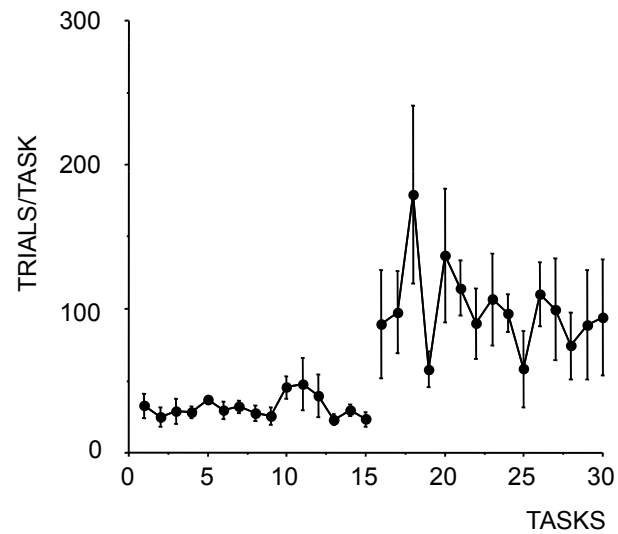

color discrimination

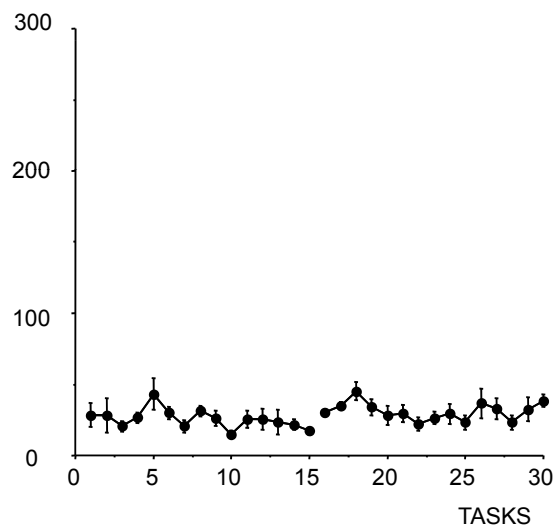

Figure 5. Effects of hippocampal lesions on repeated acquisition of spatial discrimination. The figure is based on data of Watanabe (2001a). The hippocampal lesions caused deficits in acquisition of the spatial discrimination (left) but no deficits in color discrimination.

して海馬に送られる。一方鳥類海馬では視覚入力は 海馬傍部を介して海馬におくられる。ところが，先 ほど説明した $2 つ の$ 視覚系のうち，間脳一大脳系は 海馬傍部に線維を送っていない。つまり内外套は海 馬への出力を持たず, 高外套が背側高外套から海馬 傍部に投射しているのである。そのため, 高外套損 傷は海馬への視覚入力阻害となり, 海馬損傷を模倣 したような障害が起きるわけである。視覚認知実験
とは指標が異なるが，高外套と内外套の損傷効果に ついては視覚認知と空間認知で Figure 6 のような 二重乘離が認められる。

この課題は空間認知課題と考えられるが，通常の 空間認知課題はモリス迷路や放射状迷路のように被 験体の体の移動を伴ら課題である。そこで, ドイツ のビーレフェルト大学の協力を得てキンカチョウを 用いた一連の実験を行った (Watanabe \& Bischof,
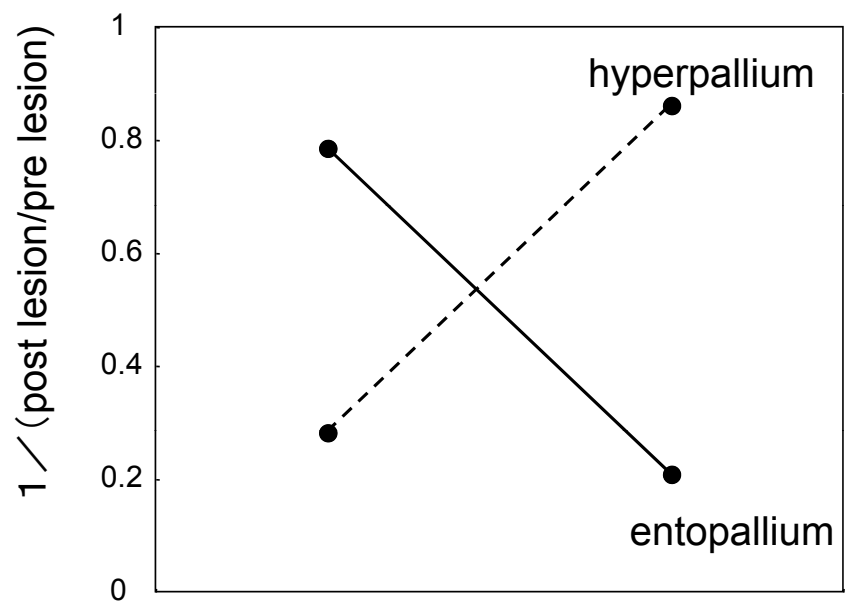

1

0.8

0.6

0.4

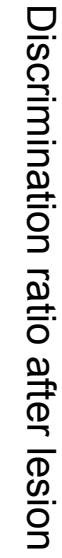

0.2

\section{Spatial cognition Individual cognition}

Figure 6. Double dissociation of function of the hyperpallium and the entopallium. The vertical axis for the spatial task is reverse of post/pre lesion ratio, and that for the visual cognitive task is discrimination ratio after the lesions. Data from Watanabe $(1992 ; 1996 ; 2003)$. 
2002)。キンカチョウを4 カ所の入り口のひとつか ら実験室に放す。実験室内には 4 力所の餌箱がある が，一力所のみが正解で餌を得ることができるが， 他は餌を得ることができない。被験体はどの入り口 から入ったかにか関わらず特定の位置の慨箱を憶え なくてはならない。キンカチョウは 1 日 4 試行の訓 練数日でこの課題を学習することができる。そこで 海馬損傷を行うと障害が見られる (Watanabe \& Bischof, 2004)。しかし, 内外套損傷では行動に変 化はない。次に餌箱に縞または点の模様をつけて, 位置ではなくパターンの弁別を行わせる。これも数 日で学習できるが, 海馬損傷と内外套損傷を行うと,

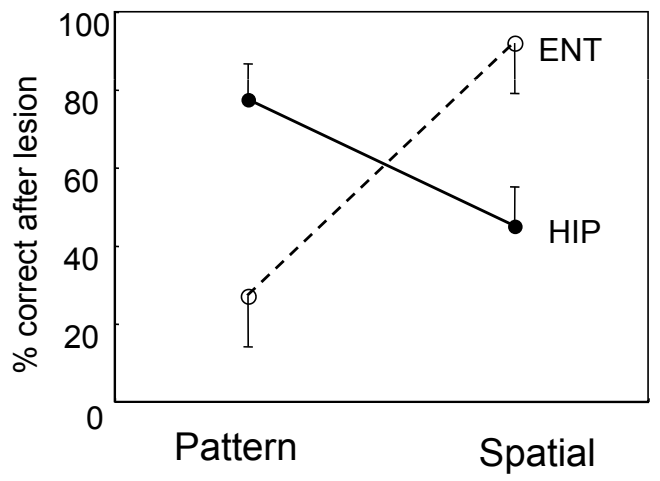

Figure 7. double dissociation of function of the entopallium and the hippocampus in zebra finches. Data from Watanabe et al., (2008).
今度は内外套損傷で選択的に障害がでる (Watanabe et al., 2008)。すなわち, 海馬と内外套で部位と課 題の二重乘離が得られる。このことは八トの連続位 置学習の結果と一致する。キンカチョウ高外套損傷 については十分なデータの蓄積に至っていないが予 備的な実験では空間課題で障害がでる。高外套損傷 で海馬損傷類似の効果がでる。

そのようなことから，つぎのような鳥類視覚系の モデルが考えられる。網膜からの出力は視蓋と背側 視床に分かれる。前者は視床円形核に投射し，そこ から内外套にいく。視蓋では哺乳類の外側膝状体と 同じように網膜像が復元されている。網膜からは視 蓋の深い層にいくものと浅い層にいくものとがわか れる。深い層では動きに選択性のある細胞が見つか る。深いところにいく経路は視床円形核尾側に投射 し，視蓋の浅い層からは円形核吻側にいたる。さら に円形核尾側からは内外套尾側一, 円形核吻側から は内外套吻側にいたる。内外套で円形核からの投射 を受けるのはその中心部で，そこから周辺部へいき， 巣外套を経て, 外套の外に出力する。内外套の吻側 経路が物の形，尾側経路が動きの分析をすると考え られている。内外套吻側からはさらに巣外套前部へ, 内外套尾側加ら巣外套中間部一連絡する。巣外套 は多感覚的な領域になるので, 純粋な視覚処理は内 外套までといらことになる。これが “What” 関 わる分析の系である。

もら一方の経路は網膜から背側視床にいき, 高外 套に到る。高外套はいくつかの層にわかれており，
"Where"

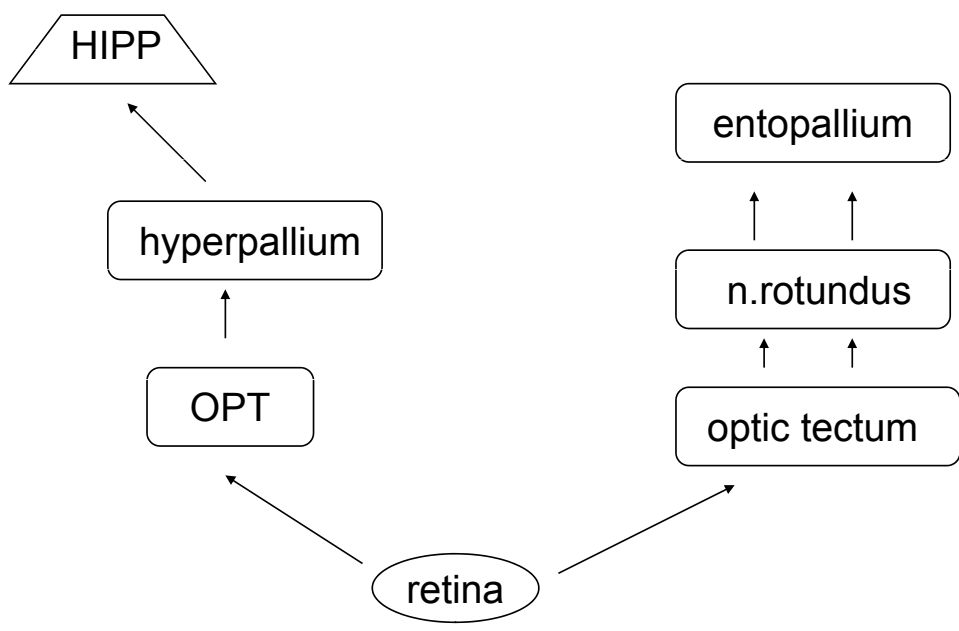

Figure 8. Hypothetical flow of "Where" (left) and "What" (right) in avian brains. See text for explanation. 
視床からの投射をらけるのは介在行外套でここから 最上介在高外套と背側高外套にいき, 副高外套にい き, 高外套外に出力する。このうち背側高外套が海 馬傍部へ投射を行っている。これが鳥類における

“Where”関わる系である。

しかし，まだ不明な点も多い。特に網膜像が再現 されており, 空間位置の分析がなされている視蓋で の “Where” の処理と高外套一海馬系での空間処理 の関係は解明されていない。

\section{7 ) まとめ}

ハトは一見するとヒト類似の高次視覚認知を行っ ているように見える。このこと自体は, 高次視覚認 知は哺乳類の中の霊長類にだけ生じたことではなく, 生物学的類縁の離れた異なる系統で独立に進化した ものであることを示している，さらにそこには高次 視覚認知を必要とした共通の系統発生的随伴性が想 定される。筆者が繰り返し主張していることなので 詳細には述べないが, 昼行性であること, 樹間生活 であることなどが，色覚や高次視覚認知を生み出し た随伴性と考えられる。詳細な研究は行われていな いが，同じように昼行性で樹間生活のリスは毒歯類 でも色覚や高次視覚認知を持つと思われる。

それでは，なぜヒトとハトが異なる脳構造で高次 視覚認知を実現しているのか。ひとつのストーリー は哺乳類が本来の視覚脳である中脳を進化させそこ なったといらものである。祖型哺乳類の夜行性, 穴 居性などといった生活様式が中脳視覚系の発達を妨 げ，逆に嗅覚脳である大脳の発達を促したと考えら れる。霊長類が昼行性, 樹間生活といら視覚に依存 した生活に転身した際に中脳ではなく大脳を利用し た視覚情報処理を発達させたとするものである。視 蓋一内外套系による核構造での処理と視床一視覚皮 質系による層構造処理では, 系による制限, いわば 工学的制約が異なる。ハトとヒトの高次視覚認知の 相違点はもちろん行動研究によって今後明らかにさ れていくと思うが, その相違を脳構造の相違に関連 づけた時に高次視覚認知の系統発生的随伴性があき らかにされると思う。

冒頭に述べたように神経解剖学は形の学問であり, 心理学や認知科学は形を捨象した機能の学問である。 しかし，機能を形によって説明することは生物を対 象とする学問の王道であろう。比較認知科学と比較 神経解剖学の統合を心より望む次第である。

(なお，本稿の一部は Watanabe， S. 2006 The neural basis of cognitive flexibility in birds. In Zentall, T. \& Wasserman, E. (Eds) Comparative Cognition: Experimental Exploration of Animal Intelligence. Oxford University Press ; Watanabe, S. \& Hofman. M. (Eds) 2007 Integration of comparative neuroanatomy and cognition. Keio Univ. Press ; 渡辺茂 · 小嶋 祥三 2007 脳科学と心の進化 岩波書店 に詳細 に論じられている。参照していただければ幸いであ る。)

\section{引用 文 献}

Baron, G. 2007 Encephalization: Comparative studies of brain size and structure volume in mammals. In Kaas, J. H. (Ed.) Evolution of nervous systems: A comprehensive reference. Elsevier, Oxford, vol 3, Pp. 125-135.

Barton, R. A., \& Harvey, P. H. 2000 Mosaic evolution of brain structure in mammals. Nature, 405, 1055-1058.

Dubois, E. 1987 Sur le rapport du poids de l'encephale avec la grandeur du corps les mammaliferes. Bulletine de la sociele d'amthropologie de Paris, 8, 337-376.

Edinger, L. 1908 The relations of comparative anatomy to comparative psychology. Jour nal of Comparative Neurology, 18, 437-457.

Griffine, D. R. 1976 The questions of animal awareness: evolutionary continuity of mental experiences. Rockfeller University Press, New York.

Healy, S. D., \& Rowe, C. 2007 A critique of comparative studies of brain size. Proceedings of the Royal Society of London B, 274, 453-464.

Herrnstein, R. J, \& Loveland, D. H. 1964 Complex visual concept in the pigeon. Science, 146, 549-551.

Hofman, M. A. 2001 Evolution and complexity of the human brain: some organizing principles. In Roth, G. \& Wullimann, M. F. (Eds) Brain evolution and cognition. Wiley and Sons, New York, Pp. 501-521.

Jerison, H. J. 1973 Evolution of brain and intelligence. Academic Press, New York.

Johnston, J. B. 1923 Further contributions of the study of the evolution of the forebrain, Journal of Comparative Neurology, 36, $143-192$.

Lorenz, K. 1978 Vergleicehnde Verhaltensforsc- 
hung: Grundlagen der Ethologie. SpringerVerlag, Wien-New York.

MacLean, P. D. 1970 The triune brain, emotion and scientific bias. In Schmitt, F. O. (Ed.) The neuroscience second study program Rockefeller Univ Press New York, Pp. 336-349.

Maier N. R. F., \& Schneila. T. C. 1935 Principles of animal psychology. McGrawHill, New York.

Morgan, C. L. 1894 An introduction to comparative psychology. Walter Scott Limited, London.

Nieuwenhuys, R. 1998 Comparative neuroanatomy: Place, principles and program. In Nieuwenhuys, R, Ten Donkelaar, H. J., \& Nicholson. (Eds.) The central nervous system of vertebrates. Springer-Verlag, Berlin, vol. 1, Pp. 273-326.

Northcutt, R. G. 1984 Evolution of the vertebrate central nervous system: Pattern and processes. American Zoology, 24, 701716.

O’Keef, J., \& Nadel, L. 1978 The hippocampus as a cognitive map. Oxford Univ. Press, Oxford.

Reiner, A. et al. 2004 Revised nomenclature for avian telencephalon and some related brainstem nuclei. Journal of Comparative Neurology, 473, 377-414.

Romanes, G. J. 1883 Animal intelligence. Appleton \& Company, New York.

Simpson, G. G. 1961 Principles of animal taxonomy. Columbia University Press, New York.

Streider, G. F. 2007 A history of ideas in evolutionary neuroscience. In Kaas, J. H. (Ed.) Evolution of nervous system: $A$ comprehensive reference. Elsevier, Oxford vol. 1, Pp. 1-15.

von Bonin, G. 1937 Brain weight and body weight in mammals. Journal of General Psychology, 16, 379-389.

Washburn, M. F. 1917 The animal mind: A textbook of comparative psychology. MaCmillan, New York.

Watanabe, S. 1991 Effects of ectostriatal lesions on natural concept, pseudoconcept and artificial pattern discrimination in pigeons. Visual Neuroscience, 6, 497-506.

Watanabe, S. 1992 Effects of ectostriatum and Wulst lesions on individual and species discrimination in pigeons. Behavioural Brain Research, 49, 197-203.

Watanabe, S. 1996 Effects of ectostriatal lesions on concepcific, species and familiar object discrimination in pigeons. Behavioural Brain Research, 81, 183-188.

渡辺茂（編）1998 心の比較認知科学. ミネルヴァ 書房.

Watanabe, S. 2001a Effects of hippocampal lesions on repeated acquisition of spatial discrimination in pigeons. Behavioural Brain Research, 120, 59-66.

Watanabe, S. 2001b Gogh, Chagall and pigeons. Animal Cognition, 4, 147-151.

Watanabe, S. 2003 Effects of Wulst and ectostriatal lesions on repeated acqusition of spatial learning in pigeons. Cognitive Brain Research, 17, 286-292.

Watanabe, S. 2006 The neural basis of cognitive flexibility in birds. In Zentall, T. \& Wasserman, E. (Eds) Comparative Cognition: Experimental Exploration of Animal Intelligence. Oxford University Press.

Watanabe, S., \& Bischof, H-J. 2002 Spatial learning in song bird. Current Psychological Letters, 3, 71-80.

Watanabe, S., \& Bischof, H-J. 2004 Effects of hippocampal lesions on acquisition and retention of spatial learning in zebra finches. Behavioural Brain Research, 155, 147-152.

Watanabe, S. Maier, U., \& Bischof, H-J. 2008 Pattern discrimination is affected by entopallial but not by hippocampal lesions in zebra finches. Behavioural Brain Research, 19, 201-205.

Watanabe, S., Wakita, M., \& Sakamoto, J. 1995 Pigeons' discrimination of paintings by Monet and Picasso. Journal of the Experimental Analysis of Behavior, 63, 165-174.

Wundt, W. 1894 Lectures on human and animal psychology. (translated by J. E. Creighton \& E. B. Titchener) Swan Sonnesschein \& Co., New York.

(2008. 10. 12 受稿, 2008.11. 5 受理) 